\title{
PEMETAAN KUALITAS MADRASAH ALIYAH DI KABUPATEN BONE BOLANGO PROVINSI GORONTALO
}

\author{
The Mapping of Islamic Senior High Schools Quality \\ in Bone Bolanga Regency, Gorontalo Province
}

\author{
Baso Marannu \\ Balai Penelitian dan Pengembangan Agama Makassar \\ Jl. A.P. Pettarani No. 72 Makassar \\ Email: athobasomarannu70@gmail.com
}

Naskah diterima tanggal 9 Januari 2014. Naskah direvisi tanggal 25 Maret 2014.Naskah disetujui tanggal 22 April 2014

\begin{abstract}
Abstrak
Penelitian kualitas Madrasah Aliyah ini bertujuan untuk menganalisis secara kritis tentang pelaksanaan delapan komponen Standar Nasional Pendidikan di Madrasah Aliyah sebagaimana yang tertuang dalam Peraturan Pemerintah nomor 19 tahun 2005 yang diperbaharui dengan PP nomor 23 tahun 2013, kemudian mempetakannya dalam matrik yang sederhana. Studi ini dilakukan pada Madrasah Aliyah Negeri dan swasta di Kabupaten Bone Bolango provinsi Gorontalo menggunakan pendekatan kualitatif dan pengamatan secara langsung implementasi kedelapan komponen Standar Nasional Pendidikan. Hasil dari studi ini menyimpulkan madrasah sebagai lembaga pendidikan Islam, terutama manajemen pengelolaan standar nasional pendidikan menuju madrasah yang memiliki integritas, akuntabilitas, dan kredibilitas, Ada delapan hal yang menjadi pemikiran kritis menuju madrasah berkualitas secara umum yang kemudian diistilahkan dengan delapan Strategi Nilai Pilihan, yakni (1) membuat kurikulum inovatif (2) penambahan jam pelajaran; (3) lulus di atas 95\% di perguruan tinggi pavorit (4) terjagannya profesional pendidik; (5) sarana dan prasarana memadai; (6) pembiayaan di atas rata-rata; (7) pengelolaan manajemen pendidikan berjalan baik (8) sistem penilaian di atas SNP, dimana kedelapan hal tersebut menjadi tantangan bagi madrasah yang ingin dikatakan berkualitas.
\end{abstract}

Kata kunci: pemetaan, kualitas madrasah, standar nasional pendidikan

\begin{abstract}
This research was about the quality of Islamic senior high schools which aimed at analyzing critically about the implementation the eight components of National Education Standard in Islamic senior high schools as mentioned on the government rule number 19, 2005 which was renewed by the government rule number 23, 2013, then mapped in the simple matrix. The research was conducted in the state and private Islamic senior high schools in Bone Bolanga regency, Gorontalo province. The research used the qualitative approach and direct observation toward the implementation of the eight components of National Education Standard. The result of the research was concluded that Islamic senior high schools as Islamic education institution, specially the management of National Education Standard through the Islamic schools which have integrity, accountability, and credibility. There are eight things becoming the critical mind toward generally qualified Islamic senior high schools then got a technical term as eight strategies of value choice are: 1. making innovative curriculum 2. adding teaching hours 3. being admitted about above $95 \%$ in favorite universities 4. keeping the professionalism of educators 5. being adequate infrastructures 6. above rate cost 7. managing education well 8. the grade system above National Education Standard. The eight requirements become the challenge for Islamic senior high schools which want to be the qualified schools.
\end{abstract}

Keywords: mapping, the quality of islamic senior high schools, national education standard 


\section{PENDAHULUAN}

$\mathrm{D}$ alam konteks Indonesia, sebagaimana yang ditulis oleh Faturrachman bahwa madrasah mulai lahir pada awal abad ke-20, tepatnya tahun 1905, yaitu Madrasah Mambaul Ulum di Kesultanan Surakarta, berdekatan dengan waktu berdirinya Madrasah Diniyah Labai al-Yunusiyah di Sumatera. Kemudian, madrasah pun berkembang di Sumatera dan Jawa. Di Sumatera berdiri Madrasah At-Tawalib yang didirikan oleh Syaikh Abdul Karim Abdullah di Padang demikian seterusnya juga berkembang di pulau Jawa. berdirinya madrasah di Indonesia lahir sebagai respon, bahkan sebagai tandingan terhadap pendidikan modern yang di kelola pemerintah Belanda untuk mereka dan beberapa masyarakat sebagai basis pendukungnya, sementara rakyat secara umum, khususnya umat Islam tidak mendapatkan pendidikan berkualitas. (Asmani, 2013:22-25).

Gerakan modernisasi pendidikan Islam yang mengkristal kepada madrasah modern merupakan bagian dari gerakan modernisasi Islam Indonesia secara keseluruhan. Akan tetapi, tak dapat dimungkiri bahwa penyebaran madrasah yang demikian cepat menjadikan lembaga ini mengalami diversifikasi dan kompleksitas (Subhan, 2012:133).

Konfrensi internasional pertama tentang Pendidikan Islam di Mekkah pada tahun 1977 merumuskan pendidikan Islam sebagai berikut: "Pendidikan bertujuan mencapai pertumbuhan kepribadian manusia yang menyeluruh secara seimbang melalui latihan jiwa, intelek, diri manusia yang rasional; perasaan dan indra. Karena itu pendidikan harus mencakup pertumbuhan manusia dalam segala aspeknya: spiritual, intelektual, imajinasi, fisik, ilmiah, bahasa, baik secara individual maupun secara kolektif, dan mendorong semua aspek ini kearah kebaikan dan mencapai kesempurnaan. Tujuan akhir pendidikan muslim terletak pada perwujudan ketundukan yang sempurna kepada Allah baik secara pribadi, komunitas maupun seluruh umat manusia (Azra, 2012:64).

Kebijakan pembangunan pendidikan Nasional diarahkan pada upaya mewujudkan daya saing, pencitraan publik, dan akuntabilitas penyelenggaraan pendidikan. Tolok ukur efektivitas implementasi kebijakan tersebut dilihat dari ketercapaian indikator-indikator mutu penyelenggaraan pendidikan yang telah ditetapkan BNSP dalam delapan Standar Nasional Pendidikan (SNP).

Peraturan Pemerintah Nomor 32 Tahun 2013 tentang Perubahan atas Peraturan Pemerintah No. 19 tahun 2005 tentang Standar Nasional Pendidikan bertujuan untuk meningkatkan mutu pendidikan di Indonesia. Standar Nasional Pendidikan (SNP) terdiri dari: (1) Standar Kompetensi Lulusan; (2) Standar Isi; (3) Standar Proses; (4) Standar Pendidik dan Tenaga Kependidikan; (5) Standar Sarana dan Prasarana; (6) Standar Pengelolaan; (7) Standar Pembiayaan; (8) Standar Penilaian Pendidikan.

Lahirnya Undang Undang Sisdiknas No. 20 tahun 2003 menempatkan madrasah pada posisi sebagai sekolah umum. Posisi ini menuntut adanya peningkatan kualitas dalam penyelenggaraan pendidikan, sehingga dapat menghasilkan lulusan yang berkualitas, memiliki daya saing di pasaran serta mampu menghadapi tantangan zaman.

Berbicara tentang mutu pendidikan, maka kita tidak akan terlepas dari sistem akreditasi yang telah terstandarisasi secara Nasional. Akreditasi merupakan salah satu "mantra" baru dalam upaya peningkatan dan penjaminan mutu pendidikan nasional pada umumnya dan pendidikan madrasah pada khususnya sesuai dengan Standar Nasional Pendidikan. Salah satu tujuan penting dari kebijakan akreditasi adalah untuk menentukan kelayakan satuan pendidikan pada jalur pendidikan formal dan nonformal pada setiap jenjang dan jenis pendidikan dalam rangka memenuhi 8 (delapan) Standar Nasional Pendidikan (Direktur Pendidikan Madrasah, 2011)

Bahkan Berdasarkan Rencana Strategis Direktorat Jenderal Pendidikan Islam, pada tahun 2014 seluruh satuan pendidikan madrasah dari RA, Ml, MTs, dan MA harus sudah diakreditasi dan 50\% minimal terakreditasi B. Hal ini menjadi tantangan besar Kementerian Agama saat ini. Pasalnya, dalam konteks madrasah, kebijakan nasional akreditasi sekolah/madrasah sebagaimana tersebut di atas mempunyai implikasi yang cukup serius.

Data Statistik Pendidikan Agama \& Keagamaan Tahun 2008 menyebutkan bahwa sekitar 90\% madrasah berstatus swasta. Fenomena 
umum menunjukkan bahwa secara umum kondisi madrasah swasta di Indonesia cenderung berhadapan dengan kultur kemiskinan (culture of poverty) di mana sebagian besar wali murid siswa madrasah berasal dari golongan ekonomi menengah ke bawah (Ml 78,6\%; MTs 76,5\%; MA 60,9\%) (Statistik Pendidikan Agama \& Keagamaan, 2008).

Sementara itu, data BAN-S/M menunjukkan bahwa sampai tahun 2009 jumlah madrasah yang telah terakreditasi hanya $26,03 \%(15,211)$ yang terdiri atas 21,97\% (RA), 25\% (Ml), 29,56\% (MTs), dan $37,01 \%$ (MA). Jumlah total madrasah yang belum diakreditasi oleh BAN-S/M adalah 43.228 madrasah yang terdiri atas 14,368 (RA), 16,958 (Ml), 8,804 (MTs), dan 3,098 (MA). Dengan demikian, tantangan Kementerian Agama dalam menghadapi proses akreditasi madrasah sangat besar saat ini.

Salah satu tantangan besar Kementerian Agama saat ini dalam konteks pembinaan dan peningkatan mutu pendidikan madrasah saat ini adalah Akreditasi Madrasah. Persoalan Akreditasi menjadi penting dan urgen untuk menjawab tantangan tersebut, Direktorat Jenderal Pendidikan Islam telah menetapkan Rencana Strategis Direktorat Jenderal Pendidikan Islam 2010-2014 yang menempatkan masalah penuntasan akreditasi madrasah menjadi prioritas penting.

Berdasarkan Rencana Strategis Direktorat Jenderal Pendidikan Islam, pada tahun 2014 seluruh satuan pendidikan madrasah dari RA, Ml, MTs, dan MA harus sudah diakreditasi dan 50\% minimal Terakreditasi B. Hal ini menjadi tantangan besar Kementerian Agama saat ini. Data BAN-S/M menunjukkan bahwa sampai tahun 2010 jumlah madrasah yang telah terakreditasi hanya $26,03 \%$ $(15,211)$ yang terdiri atas $21,97 \%$ (RA), $25 \%(\mathrm{Ml})$, 29,56\% (MTs), dan 37,01\% (MA). Jumlah total madrasah yang belum diakreditasi oleh BAN-S/M adalah 43.228 madrasah yang terdiri atas 14,368 (RA), 16,958 (Ml), 8,804 (MTs), dan 3,098 (MA). Dengan demikian, tantangan Kementerian Agama dalam menghadapi akreditasi sekolah/madrasah masih sangat besar.

\section{Tinjauan Pustaka \\ Pengertian dan Penjaminan Mutu dalam Pendidikan}

Pengembangan mutu dalam sektor pendidikan, sesungguhnya mengadopsi dari berbagai konsep terutama konsep mutu dalam dunia industri. Pada perkembangannya mutu pendidikan menjadi suatu konsep "paten" sehingga mutu pendidikan menjadi kebutuhan primer bagi sekolah untuk bersaing dengan sekolah-sekolah lainnya.

Pengertian umum mutu mengandung makna derajat (tingkat) keunggulan suatu produk (hasil kerja/ upaya) baik berupa barang maupun jasa, baik yang tangible maupun yang intangible. Dalam konteks pendidikan pengertian mutu dalam hal ini mengacu pada "proses pendidikan" dan "hasil pendidikan". Dalam proses pendidikan yang bermutu terlibat berbagai input, seperti bahan ajar (kognitif, afektif dan psikomotorik), metodologi (bervariasi sesuai dengan kemampuan guru), sarana sekolah serta dukungan administrasi dan sarana prasarana dan sumber daya lainnya serta penciptaan suasana yang kondusif (Suryosubroto, 2004:210).

Dalam konteks pendidikan, Pengertian mutu mengacu pada masukan, proses, luaran dan dampaknya. Mutu masukan dapat dilihat dari beberapa sisi. Pertama, kondisi baik atau tidaknya masukan sumber daya manusia. Kedua, memenuhi atau tidaknya kriteria masukan material. Ketiga memenuhi atau tidaknya kriteria masukan berupa perangkat lunak. Keempat mutu masukan berupa harapan dan kebutuhan (Danim, 2008:53).

Sedangkan menurut Arcaro transformasi menuju sekolah bermutu terpadu diawali dengan mengadopsi dedikasi bersama terhadap mutu oleh dewan sekolah, administrator, staf, siswa dan komunitas sekolah. (Arcaro, 2007:10). Mutu dalam pendidikan adalah hasil prestasi yang dicapai sekolah dalam kurun waktu tertentu (Gozali, 2011:132).

Hal lainnya, dalam konteks pendidikan, Quality in fact merupakan profil lulusan institusi pendidikan yang sesuai dengan kualifikasi tujuan yang berbentuk standar kemampuan dasar atau kualifikasi akademik minimal yang dikuasai oleh peserta didik, sedangkan pada Quality in Perseption, pendidikan adalah kepuasan dan bertambahnya minat pelanggan terhadap lulusan pendidikan (Zazin. 2011:62). 
Gambar 1 Piramida Penjaminan Mutu

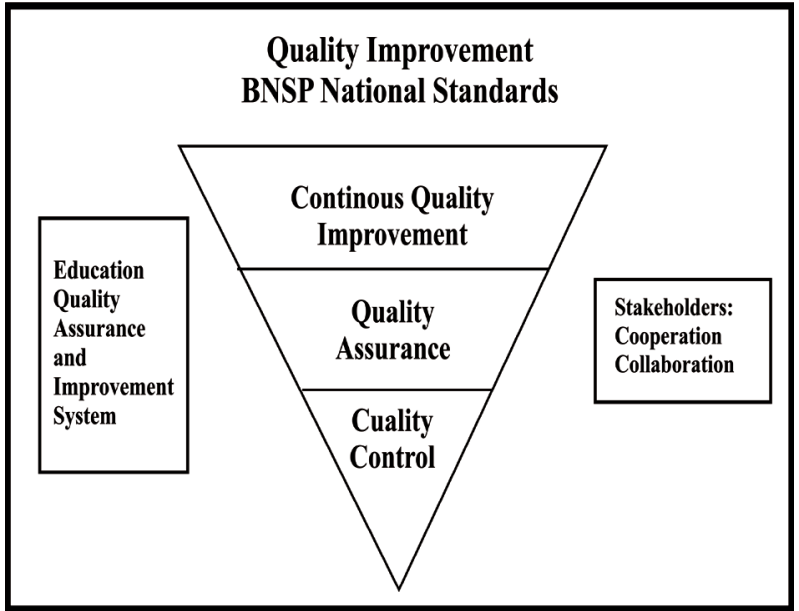

Sumber: Amri, Sofan. 2013. Peningkatan Mutu Pendidikan Sekolah Dasar dan Menengah dalam teori, konsep dan analisis. Jakarta: Prestasi Pustakarya hal 35.

Dari pendapat di atas dapat disimpulkan bahwa mutu pendidikan adalah nilai tertinggi dari input, proses, output dan outcome pendidikan, dalam kaitannya dengan pemenuhan standar nasional pendidikan, mutu pendidikan diukur melalui evaluasi, akreditasi dan sertifikasi. Gambar tersebut menjelaskan bahwa penjaminan mutu dan peningkatan mutu pendidikan memerlukan standar mutu, dilakukan dalam satu prosedur tata kerja yang jelas, strategi, kerjasama dan kolaborasi antar pemangku kepentingan; dan dilakukan secara terusmenerus berkelanjutan. Kebijakan pembangunan pendidikan pada dewasa ini menunjukkan adanya modal kuat untuk meningkatkan mutu pendidikan nasional. Delapan Standar Nasional Pendidikan menyediakan acuan untuk mengkaji pencapaian pendidikan, mutu pendidikan dan bidang yang membutuhkan peningkatan mutu pendidikan. Delapan SNP yang dimaksudkan meliputi: (1) standar isi, (2) standar proses, (3) standar kompetensi lulusan, (3) standar pendidik dan tenaga kependidikan, (5) standar sarana dan prasarana, (6) standar pengelolaan, standar pembiayaan, dan (8) standar penilaian pendidikan (Amri, 2013:35-36).
Gambar 2 Siklus Penjaminan Mutu sesuai Standar nsional

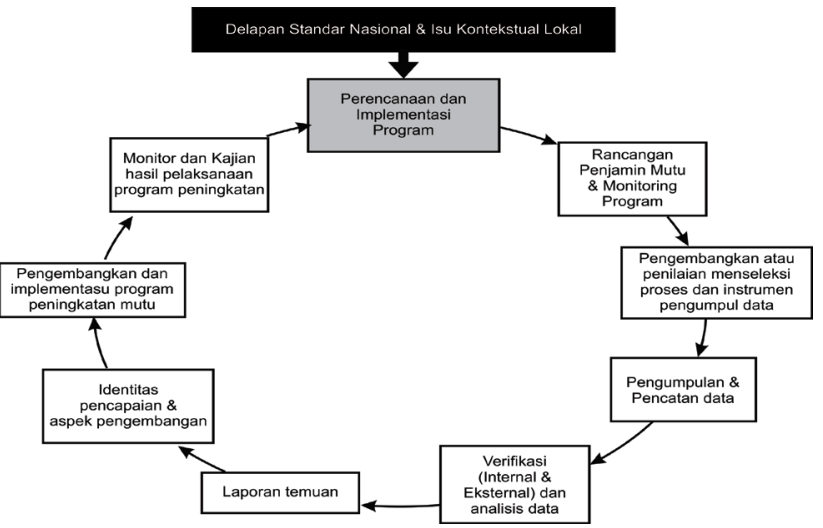

Sumber: Amri, Sofan. 2013. Peningkatan Mutu Pendidikan Sekolah Dasar dan Menengah dalam teori, konsep dan analisis. Jakarta: Prestasi Pustakarya hal 36.

Satu model yang dikembangkan lebih rinci ditawarkan dengan tahapan siklus sebagai berikut: (1) perencanaan program, (2) rancangan pelaksanaan penjaminan mutu dan monitoring program, (3) pengembangan instrumen pengumpulan data, (4) pengumpulan dan pencatatan data, (5) verifikasi dan analisis data, (6) laporan temuan, (7) identifikasi pencapaian dan aspek pengembangan, (8) pengembangan dan implementasi pengembangan mutu, (9) monitor dan kajian hasil peleksanaan program peningkatan, dan selanjutnya kembali ke tahap awal lagi yaitu perencanaan program.

\section{Pemetaan Mutu Pendidikan}

Pemetaan mutu adalah serangkaian kegiatan untuk mengetahui kondisi dan situasi yang menggambarkan peta mutu pendidikan Standar Nasional Pendidikan (SNP) yang dilakukan oleh satuan pendidikan, penyelenggara, pemerintah daerah, dan pemerintah dalam kurun waktu tertentu. Mutu pendidikan Indonesia dinilai berdasarkan capaian kinerja satuan pendidikan atas Standar Nasional Pendidikan.

Jadi pemetaan mutu pendidikan adalah serangkaian kegiatan untuk mengetahui kondisi dan situasi yang menggambarkan capaian kinerja satuan pendidikan atas SNP dalam suatu kurun waktu yang ditentukan oleh satuan pendidikan, penyelenggara pendidikan, pemerintah daerah dan pemerintah untuk menghasilkan peta mutu pendidikan. 
Penentuan kualitas penyelenggaraan pendidikan di Indonesia dilakukan melalui sistem akreditasi. Akreditasi sekolah adalah kegiatan penilaian (assesment) sekolah secara sistematis dan komprehensif melalui kegiatan evaluasi diri dan evaluasi eksternal (visitasi) untuk menentukan kelayakan dan kinerja sekolah.

Maka tak ayal lagi, minimnya data sekolah yang akurat, akuntabel, serta memiliki bobot informasi yang memiliki daya tarik baik kandungan isi maupun data kualitatif lainnya dituding sebagai indikator kunci kelemahan dalam sistem database pendidikan saat ini. Hal ini tentunya tidak diharapkan bagi seluruh komponen masyarakat pendidikan yang mengharapkan gambaran utuh profil sekolah sebagai bahan acuan penentu kebijakan dalam mengambil tindakan dan followup selanjutnya.

\section{Madrasah di Era Kompetitif}

Madrasah, secara bahasa, berasal dari kata darasa, yaitu belajar, sedangkan madrasah berarti tempat belajar atau sekolah formal. Pengertian yang biasa orang awam gunakan untuk madrasah adalah lembaga pendidikan tingkat dasar dan menengah, baik yang mengajarkan ilmu agama Islam saja, perpaduan antara ilmu agama Islam dan ilmu umum, maupun ilmu-ilmu umum yang berbasis ajaran Islam (Nata, 2012:204)

Dalam konteks Indonesia, madrasah mulai lahir pada awal abad ke-20, tepatnya tahun 1905, yaitu madrasah Mambaul Ulum di Kerajaan Surakarta, berdekatan dengan waktu berdirinya Madrasah Diniyah Labai al-Yunusiyah di Sumatera. Kemudian, madrasahpun berkembang di Sumatera dan Jawa. Di Sumatera sendiri, berdiri madrasah at-Tawalib yang didirikan oleh SyaikhAbdul Karim Amrullah di Padang Panjang (Fatchurochman, 2012:20-21).

Abdul Mujib dan Jusuf Musakkir (dalam M. Sobry Sutikno, 2012) menyebutkan empat latar belakang berdirinya madrasah, yaitu: (1) Pengejewantahan dan realisasi dari pembaharuan sistem pendidikan Islan; (2) Upaya penyempurnaan terhadap sistem pendidikan pesantren yang memberikan kesempatan kepada lulusannya untuk memperoleh kesamaan kerja dan ijasah; (3) Mentalitas sebagian umat Islam yang terpukau dengan kemajuan barat dengan sistem pendidikannya; (4) Sebagai usaha untuk menjembatani sistem pendidikan tradisional yang ada di pesantren dengan sistem pendidikan modern yang merupakan tuntutan jaman (Sutikno, 2012:186-187).

Kepemimpinan yang ada di madrasah biasanya karismatik dan sentralistik, tertumpu pada satu figur, serta belum terbangun oleh sistem yang kokoh. Ketergantungan kepada figur ini biasanya berdampak positif dan negatif. Positif, karena kepemimpinan macam ini dapat menggerakkan program secara cepat serta meminimalkan konflik terbuka dan antagonisme struktural yang bisa menghambat perkembangan madrasah. Negatif, karena dapat menyebabkan stagnasi dalam kaderisasi pemimpin untuk masa yang akan datang (Asmani, 2013:9-10).

Untuk menunjang tercapainya kualitas pendidikan di madrasah telah dikeluarkan Surat Keputusan Bersama (SKB) tiga menteri yaitu Menteri Agama, Menteri Dalam Negeri dan Menteri Pendidikan dan Kebudayaan Nomor 6/1975, 036/U/1975, dan 037/U/1975 yang antara lain menyatakan bahwa Ijazah madrasah nilainya sama dengan sekolah umum, lulusannya dapat melanjutkan atau berpindah ke sekolah umum yang setingkat (Nata, 2003:49). Kemudian terbit lagi SKB dua menteri, yaitu Menteri Agama dan Menteri Pendidikan dan Kebudayaan Nomor 299 tahun 1984 yang mengatur tentang pembakuan kurikulum sekolah umum dan madrasah (Hasballah, 1999:163).

Walaupun tidak secara umum, namun kondisi Madrasah saat ini masih ada yang jauh dari harapan label "madrasah bermutu" di tengah kemunduruan dan keterbelakangan madrasah sekarang ini, perbaikan harus dilakukan dengan langkah-langkah yang tidak biasa. Sebab jika meneruskan dan memelihara hal-hal yang menjadi rutinitas, hasilnya dapat dipastikan biasa juga. Artinya madrasah saat ini harus mampu memenangkan persaingan. Untuk itu dibutuhkan "ide-ide gila" yang akan membawa perubahan besar bagi eksistensi dan reputasi madrasah di masa mendatang (Asmani, 2013:105).

Untuk melaksanakan program mutu di madrasah maka diperlukan beberapa dasar yang kuat diantaranya: (1) komitmen pada perubahan; (2) pemahaman yang jelas terhadap kondisi yang ada; 
(3) mempunyai visi yang jelas terhadap masa depan;

(4) mempunyai rencana yang jelas (Sukmadinata, dkk. 2008:9).

Fakta di lapangan menunjukkan bahwa ada banyak kelemahan dalam praktek penyelenggaran pendidikan di madrasah. Kelemahan tersebut dapat dikelompokkan menjadi dua kategori: Pertama, Segi manajemen. Kedua, Kelemahan di bidang profesionalitas guru/SDM (Bulletin Masyarakat Pendidikan, Vol I. No.2.2001).

Kelemahan mutu lulusan. Problem SDM dan sarana/prasarana pada gilirannya memunculkan problem mutu atau kualitas proses belajar mengajar yang rendah. Karena guru tidak memiliki kecakapan akademis dan metodologis yang mencukupi, sehingga proses belajar mengajar hanya sampai pada tingkat transfer pengetahuan, dari pengetahuan yang dimiliki guru kepada murid. Oleh sebab itu, agak sulit diharapkan anak didik memiliki informasi ilmu pengetahuan yang baru. Apalagi bersamaan dengan itu, pendekatan pendidikan kreatif dan liberatif, sebagai sebuah pendekatan pendidikan menuju kemandirian berpikir anak, tidak pernah dikembangkan. Demikian juga teknologi-teknologi pembelajaran mutakhir lainnya (Soekartawi, 1995:123)

Lokasi Penelitian. Penelitian ini akan di lakukan Kabupaten Bone Bolango Provinsi Gorontalo. Pada lokasi 1) Madrasah Aliyah Negeri Insan Cendikia; 2) Madrasah Aliyah Swasta Muhammadiyah Kabila; 3) Madrasah Aliyah Swasta Sabrun Jamil. Penelitian ini merupakan penelitian Kualitatif, Peneliti ini mencoba memperoleh gambaran jelas tentang kualitas Madrasah Aliyah mulai dari input, proses hingga output.

Masalah Penelitian, Penelitian ini akan mendalami dan mengobservasi pada dua hal pokok permasalahan, pertama bagaimana kualitas madrasah Aliyah di Kabupaten Bone Bolango Provinsi Gorontalo yang berlandaskan pada Peraturan Pemerintah No. 19 tahun 2005 dan PP Nomor 32 tahun 2013 tentang perubahan atas peratuan pemerintah No. 19 tahun 2005 dengan beracuan pada delapan standar yang telah ditetapkan oleh pemerintah? Kedua bagaimana peta kualitas madrasah Aliyah di Kabupaten Bone Bolango? yang kemudian digambarkan dalam bentuk grafik serta matrik informasi sederhana.

Penelitian bertujuan untuk mengetahui menganalisadan memberikan solusiyangkonstruktif terhadap kualitas Madrasah Aliyah di Kabupaten Bone Bolango terutama pada delapan aspek standar pendidikan, setelah itu dipetakan kualitas tersebut dalam sebuah matriks informasi yang dapat dengan mudah di amati tingkat kualitasnya oleh pemangku kebijakan dalam hal ini adalah Kementerian Agama terkhusus Direktur Pendidikan Madrasah.

\section{METODE PENELITIAN}

Penelitian ini dilakukan di Kabupaten Bone Bolango, sebuah kabupaten di Provinsi Gorontalo. Penelitian ini menyasar tiga lokasi yaitu: Madrasah Aliyah Negeri Insan Cendikia; Madrasah Aliyah Swasta Muhammadiyah Kabila; dan Madrasah Aliyah Swasta Sabrun Jamil. Penelitian ini berlandaskan pada Peraturan Pemerintah Nomor 19 tahun 2005 tentang Standar Nasional Pendidikan bertujuan untuk meningkatkan mutu pendidikan di Indonesia.

Penelitian ini merupakan penelitian Kualitatif, yang ingin diketahui adalah mengenai tanggapan pendidik dan tenaga kependidikan serta peserta didik mengenai kualitas penyelenggaraan pendidikan di Madrasah Aliyah secara umum di Provinsi Gorontalo dan secara khusus pada ketiga Madrasah Aliyah yang berada di Kabupaten Bone Bolango.

Teknik pengumpulan data, instrumeninstrumen yang digunakan untuk menggali data dalam penelitian ini didapat dengan menggunakan beberapa teknik yaitu: teknik observasi; teknik wawancara; dan teknik dokumentasi. Adapun langkah langkah yang digunakan dalam analisis ini adalah reduksi data, penyajian data dan verifikasi data (Sugiono, 2005:92). 
PEMBAHASAN

\section{Profil Madrasah Aliyah Negeri Insan Cendekia Gorontalo}

\begin{tabular}{cc}
\multicolumn{2}{c}{ Tabel 1 Nilai Kualitas MAN Insan Cendikia } \\
\hline KOMPONEN KUALITAS & MAN INSAN \\
NAMA MADRASYAH & CENDIKIA \\
\hline Standar Isi & 96,67 \\
Standar Proses & 100,00 \\
Standar Kompetensi Lulusan & 100,00 \\
Standar Pendidikan Tenaga & 100,00 \\
Kependidikan & \\
Standar Pendidikan Dan & 99,17 \\
Prasarana & \\
Standar Pengelolaan & 100,00 \\
Standar Pembiayaan & 98,00 \\
Standar Penilaian & 98,75 \\
Pendidikan & \\
\hline
\end{tabular}

Sumber Data: BAN S/M 2012

Madrasah Aliyah Insan cendikia (MAN IC) terletak di jalan Tapa-Suwawa Desa Moutong Kecamatan Tilongkabila Kabupaten Bone Bolango Provinsi Gorontalo.

Sejarah awal pada tahun 1996 BPPT (Badan Pengkajian dan Penerapan Teknologi) yang saat itu dipimpin, Bapak Prof. Dr. Ing.B.J. Habibie melalui Program Penyetaraan Ilmu Pengetahuan dan Teknologi (Science and Technology Equity ProgramSTEP) bagi sekolah-sekolah di lingkungan pesantren, telah mendirikan SMU Insan Cendekia di Serpong (Banten) dan Gorontalo. Pada saat itu, sekolah ini dikenal dengan sebutan sekolah magnet (magnet school), dengan filosofi bahwa sekolah ini diharapkan mampu menarik sekolah-sekolah lain di sekitarnya untuk berpacu dalam prestasi, dan lebih giat memacu diri untuk mempersiapkan anak bangsa menatap masa depan.

Sejak tahun pelajaran 2000/2001 SMU Insan Cendekia di Serpong dan Gorontalo dilimpahkan pengelolaannya dari BPPT kepada Departemen Agama. Untuk mempertahankan ciri khas penguasaan iptek dan imtak dalam pengelolaan dan pembinaannya, Departemen Agama tetap bekerjasama dengan BPPT. Selanjutnya nama SMU Insan Cendekia ditransformasikan menjadi Madrasah Aliyah Negeri Insan Cendekia tanpa mengurangi materi maupun sistem pembelajaran yang telah berjalan selama ini.
Pada tahun 2001, dengan SK Menteri Agama RI, Nomor 490 Tahun 2001 MA Insan Cendekia Serpong dan Gorontalo berubah menjadi Madrasah Aliyah Negeri (MAN) Insan Cendekia Gorontalo dan Madrasah Aliyah Negeri (MAN) Insan Cendekia Serpong. Suasana MAN Insan Cendikia memang cukup representatif bahkan hampir dikatakan mewah, karena semua fasilitas yang dimiliki untuk mendukung kualitas penyelenggaraan pendidiklan tergolong lengkap dan berkualitas, hal ini karena mendapat dukunga sepenuhnya dari Kementerian agama, yakni Direktur Madrasah.

\section{Profil Madrasah Aliyah Swasta Sabrun Jamil}

Tabel 2 Nilai Kualitas MAS Muhammadiyah

\begin{tabular}{cc}
\hline KOMPONEN KUALITAS/ & $\begin{array}{c}\text { MAS MUHAMMADIYAH } \\
\text { NAMA MADRASAH }\end{array}$ \\
\hline KABILA \\
\hline Standar Pri & 85,00 \\
Standar Kompetensi Lulusan & 95,00 \\
Standar Pendidikan Dan & 53,00 \\
Tenaga Kependidikan & 77,00 \\
Standar Sarana Dan & \\
$\quad$ Prasarana & 57,50 \\
Standar Pengelolaan & \\
Standar Pembiayaan & 82,50 \\
Standar Penilaian & 75,00 \\
Pendidikan & 65,00 \\
\hline
\end{tabular}

Sumber Data: BAN S/M 2012

Madrasah Sabrun Jamil (MAS SJ) terletak di jalan Sukma Batupingge Desa Luwohu Kecamatan Batupingge Kabupaten Bone Bolango Provinsi Gorontalo, sama halnya dengan MAN Insan Cendikia, MAS Sabrun Jamil, juga menggabungkan dengan lembaga pendidikan MA ini dengan sistem pesantren, walaupun ditengah kesederhanannya tapi ada semangat membangun anak-anak bangsa di sekitar pesisir Bone Bolango untuk melanjutkan pendidikan di MA Sabrun Jamil. Walaupun MA Sabrun Jamil ini swasta tapi para siswanya tidak dipungut biaya, untuk biaya hidup di asrama mereka, masing-masing siswa membawa bekal dari rumah, karena disadari bahwa siswa MA Sabrun Jamil ini rata-rata adalah mereka yang berada pada tingkat ekonomi menengah ke bawah.

Untuk mencapai MA Sabrun Jamil ini, termasuk sulit, karena selain jalan yang kurang baik, 
letaknya sekitar 150 meter dari jalan raya. Suasana Madrasah memang sedikit tertutup, pada bagian tengah terdapat lapangan bulutangkis, sekaligus digunakan untuk kegiatan ekstrakurikuler, seperti pramuka dan juga upacara bendera.

Selain Madrasah Aliyah yang dikelola juga terdapat Madrasah Tsanawiyah, jadi ruangan kelasnya terbagi dua bagian pada sisi kiri untuk proses pembelajaran siswa Madrasah Tsanawiyah, sedangkan pada bagian lainnya digunakan untuk siswa madrasah aliyah.

Jika kita melihat dari depan (pintu gerbang) memang terlihat kecil, namun lokasi MA Sabrun Jamil ini lokasinya memanjang ke belakang, walaupun hampir sebagian besar lapangan tengah mereka semen, namun nampak juga beberapa tanaman yang ditanam di pot berjejer disetiap pinggiran lapangan, suasan asri ini juga terlihat di bagian asrama baik putri maupun putra.

\section{Profil Madrasah Aliyah Swasta Muhammadiyah Kabila}

Tabel 3 Nilai Kualitas MAS Sabrun Jamil

\begin{tabular}{cc}
\hline $\begin{array}{c}\text { KOMPONEN KUALITAS/ } \\
\text { NAMA MADRASAH }\end{array}$ & MAS SABRUN JAMIL \\
\hline Standar Isi & 73,33 \\
Standar Proses & 87,50 \\
Standar Kompetensi Lulusan & 66,00 \\
Standar Pendidikan Dan & 77,50 \\
Tenaga Kependidikan & \\
Standar Sarana Dan & 60,83 \\
Prasarana & \\
Standar Pengelolaan & 78,75 \\
Standar Pembiayaan & 85,00 \\
Standar Penilaian & 85,00 \\
Pendidikan & \\
\hline Sumber Data: BAN S/M 2012 & \\
\hline
\end{tabular}

Madrasah Muhammadiyah Kabilan (MAS MK) terletak di jalan Sawah Besar No. 196 B Kecamatan Kabila Kabupaten Bone Bolango Provinsi Gorontalo Madrasah Aliyah Muhammadiyah Kabila ini merupakan salah satu MA swasta yang terdapat di Bone Bolango, Pada bagian depan terlihat gedung hanya pada sisi kiri, dimana ruangan kepala Madrasah dan ruang tata usaha bergabung, terlihat memang sederhana, dengan fasilitas yang apa adanya.
Pada bagian belakang terdapat ruangan kelas serta ruangan guru, ada juga mushollah yang sederhana terletak pada bagian belakang lokasi Madrasah Muhammadiyah. Hampir sebagian besar pekarangan madrasah ini di semen, sehingga terlihat gersang, penulis melihat sebenarnya masih bisa memanfaatkan pot-pot bunga untuk menambah keindahan madrasah ini. Lokasi tepat dipinggir jalan sawah besar, mengapa dikatakan sawah besar karena hampir sebagian besar dilingkungan Kabila terdapat hamparan sawah.

Ada beberapa hal yang masih perlu dikembangkan terutama tata kelola organisasi, pengelolaan dibawah naungan organisasi keagamaan ini masih perlu perhatian yang tinggi, mengingat lembaga ini berpotensi untuk menjadi MAS yang berkualitas.

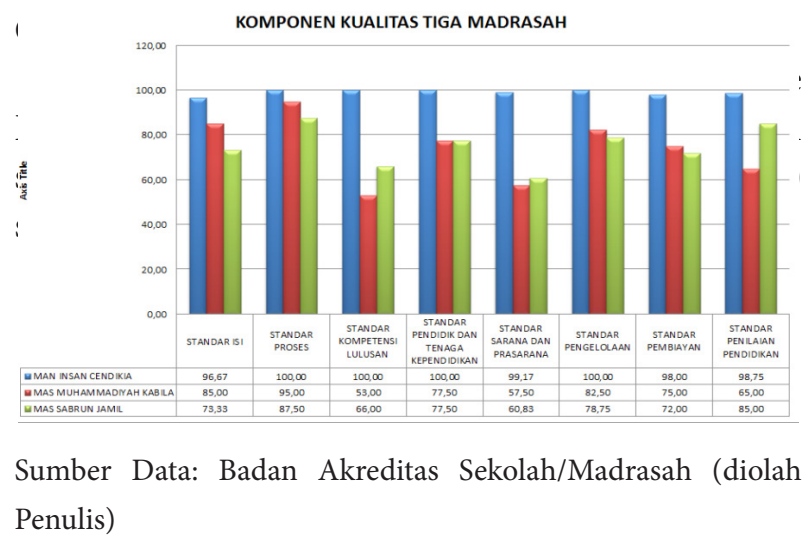

Keterangan: (1) Sangat Baik $=86-100$;

(2) Baik = $71-85$; (3) Cukup Baik = 56- 70;

(4) Kurang Baik < 55

\section{Standar Isi}

Nilai standar isi yang terdiri dari struktur kurikulum, beban belajar bagi peserta didik serta kalender pendidikan yang diperoleh oleh Insan Cendikia 96,67 masuk kategori Sangat baik sedangkan dua MAS (Muhammadiyah dan Sabrun Jamil masing-masing 85 dan 73,33 yang masuk dalam kategori Baik. Jika dirata-ratakan maka untuk ketiga madrasah tersebut memiliki nilai 85 atau kategori Baik.

Madrasah harus berani mengembangkan kurikulum sesuai dengan kebutuhan, secara umum pendekatan model pengembangan ada empat (1) model Tyler; (2) model Taba; (3) model Pendidikan 
Berbasis Hasil Belajar atau biasa disingkat dengan model PBHB; (4) model teknik saintifik; (5) model nonteknik-nonsaintifik.

Namun secara umum umum beberapa sekolah termasuk Insan Cendikia menggunakan model pengembangan kurikulum berbasis hasil belajar (outcomes based education), mencakup (a) menentukan hasil belajar; (b) Mementukan pengetahuan, kompetensi dan kinerja, (c) Menentukan cara mendesain, menyampaikan dan mendokumentasikan pembelajaran. (Arifin, 2012:63)

\section{Standar Proses}

Standar proses adalah standar nasional pendidikan yang berkaitan dengan pelaksanaan pembelajaran pada satuan pendidikan untuk mencapai kompetensi lulusan. Standar proses berisi kriteria minimal proses pembelajaran pada satuan pendidikan dasar dan menengah termasuk didalamnya perencanaan proses pembelajaran, pelaksanaan proses pembelajaran, penilaian hasil pembelajaran, dan pengawasan proses pembelajaran untuk terlaksananya proses pembelajaran yang efektif dan efisien, untuk Insan Cendikia nilainya 100 ini berarti mendapatkan nilai maksimal, sedangkan untuk Muhammadiyah standar prosesnya mendapatkan nilai 95 dan sabrun Jamil 87,50 sehingga jika dirata-ratakan nilai bagi ketiga madrasah tersebut untuk standar proses 94,17 masuk dalam kategori Sangat baik.

\section{Standar Kompetensi Lulusan}

Standar Kompetensi Lulusan adalah kriteria mengenai kualifikasi kemampuan lulusan yang mencakup sikap, pengetahuan, dan keterampilan, ini juga didominasi oleh Insan cendikia yakni 100 sementara untuk MAS Muhammadiyah mendapatkan nilai Kurang baik yakni hanya 53 sedangkan nilai untuk Sabrun Jamil 66 yakni Cukup Baik. Jika dirata-ratakan nilai yang diperoleh untuk standar kelulusan sebesar 73,00 masih tetap masuk dalam kategori Baik.

Standar kelulusan pada masing-masing madrasah, sebenarnya tergantung pada pengelola madrasah baik pendidik maupun tenaga kependidikan untuk memberikan motivasi bagi peserta didik untuk memacu diri dalam belajar, prestasi yang diharapkan, bersifat akademik (academic achievment) dan prestasi nonakademik (nonacademic achievment) (Rohiat, 2010:58).

\section{Standar Pendidik dan Tenaga Kependidikan}

Standar Pendidik dan Tenaga Kependidikan adalah kriteria mengenai pendidikan prajabatan dan kelayakan maupun mental, serta pendidikan dalam jabatan, untuk standar ini memang patut diakui bahwa Insan Cendekiamasih unggul dengan nilai maksimal yakni 100, sedangkan untuk dua MAS lainnya msing-masing 77,50. Kalau dirata-ratakan standar nilai yang diperoleh 85 Kategori Baik.

Untuk mencapai madrasah yang bermutu, maka salah satu faktor dukungan yang juga perlu diukur kualitasnya adalah pendidik. Karena dengan perkembangan saat ini jangan sampai peserta didik lebih pandai dan pendidiknya. Bahkan pernah dilakukan di Gorontalo kompetensi guru untuk mata pelajaran tertentu para pendidik mendapatkan nilai rata-rata dibawah lima, hal ini sangat memprihatinkan, artinya jika peserta didik diharapkan berkualitas maka pendidiknya juga harus berkualitas.

\section{Standar Sarana dan Prasarana}

Standar Sarana dan Prasarana adalah kriteria mengenai ruang belajar, tempat berolahraga, tempat beribadah, perpustakaan, laboratorium, bengkel kerja, tempat bermain, tempat berkreasi dan berekreasi serta sumber belajar lain, yang diperlukan untuk menunjang proses pembelajaran, termasuk penggunaan teknologi informasi dan komunikasi untuk ini Insan Cendikia memperoleh nilai 99,17 yakni Sangat Baik, MAS Muhammadiyah tergolong cukup baik yakni 57,50 sedangkan nilai untuk MAS Sabrun Jamil 60,83 jika dirata-ratakan nilainya 72,50 kategori Baik.

Untuk memenuhi standar sarana dan prasarana sebagaimana layaknya Insan Cendikia memang sulit karena membutuhkan dana yang besar, namun menurut penulis hal yang perlu dikebangkan adalah komitmen pengelola dan fokus pada apa yang menjadi unggulan madrasah.

\section{Standar Pengelolaan}

Standar Pengelolaan adalah kriteria mengenai perencanaan, pelaksanaan, dan pengawasan kegiatan 
pendidikan agar tercapai efisiensi dan efektivitas penyelenggaraan pendidikan, Insan cendikia memperoleh nilai 100 MAS Muhammadiyah dan Sabrun Jamil masing-masing 82,50 dan 78,75 atau jika dirata-ratakan nilainya 87,08 katagori Sangat baik.

Hal yang menjadi lemah pada beberapa madrasah adalah pelaksanaan dan pengawasan dari sistem manajemen madrasah yang sepakat digunakan, artinya perlu ada perhatian dalam proses melaksanakan apa yang telah direncanakan.

\section{Standar Pembiayaan}

Standar Pembiayaan adalah kriteria mengenai komponen dan besarnya biaya operasi satuan pendidikan yang berlaku selama satu tahun, untuk Insan Cendikia nilainya 98,00 kategori Sangat baik, sedangkan Muhammadiyah 75 dan Sabrun Jamil 72, atau jika dirata-rata nilainya 81,87 kategori Baik.

Konsep sumbsidi silang dari sebuah yayasan yang mengelola beberapa lembaga pendidikan harus perlu direformulasi, artinya pengelola madrasah harus mengoptimalkan keterlibatan masyarakat dalam pengembangan pendidikan.

\section{Standar Penilaian Pendidikan}

Prinsip Penilaian adalah penilaian hasil belajar peserta didik yang didasarkan pada prinsipprinsip (1) sahih, berarti penilaian didasarkan pada data yang mencerminkan kemampuan yang diukur; (2) objektif, berarti penilaian didasarkan pada prosedur dan kriteria yang jelas, tidak dipengaruhi subjektivitas penilai; (3) adil, berarti penilaian tidak menguntungkanatau merugikan pesertadidikkarena berkebutuhan khusus serta perbedaan latar belakang agama, suku, budaya, adat istiadat, status sosial ekonomi, dan gender; (4) terpadu, berarti penilaian oleh pendidik merupakan salah satu komponen yang tak terpisahkan dari kegiatan pembelajaran; (6) terbuka, berarti prosedur penilaian, kriteria penilaian; (7) menyeluruh dan berkesinambungan, berarti penilaian oleh pendidik mencakup semua aspek kompetensi dengan menggunakan berbagai teknik penilaian yang sesuai, untuk memantau perkembangan kemampuan peserta didik; (8) sistematis, berarti penilaian dilakukan secara berencana dan bertahap dengan mengikuti langkah-langkah baku; (9) beracuan kriteria, berarti penilaian didasarkan pada ukuran pencapaian kompetensi yang ditetapkan; (1) akuntabel, berarti penilaian dapat dipertanggungjawabkan, baik dari segi teknik, prosedur, maupun hasilnya untuk Insan cendikia 98,75 kategori Sangat baik sedangkan MAS Muhamadiyah 65 Cukup Baik dan Sabrun Jamil 85 yakni Baik, atau jika dirata-ratakan nilainya 82,92 yakni Baik.

Secara umum jika melihat hasil dari kesluruhan (delapan standar) yang menjadi acuan alam penelitian ini, memperlihatkan bahwa ratarata secara umum ketiga madrasah tersebut mendapatkan nilai 82,67 berati masuk kategori Baik, nilai ini dipengaruhi oleh MAS Muhammadiyah yang dalam beberapa standar memperoleh nilai yang kurang baik, sehingga secara rata-rata mempengaruhi kedua madrasah lainnya.

Untuk lebih mempertajam analisa terhadap temuan penelitian tentang kualitas Madrasah di Bone Bolango, penulis akan memberikan sebuah Analisis kritis terhadap gambaran kualitas madrasah.

Jika penelitian ini menggunakan delapan Standar Nasional Pendidikan (SNP) maka peneliti juga menganalisis hal tersebut dengan Istilah 8 SNP (Delapan Strategi Nilai Pilihan). Ke-delapan hal yang menjadi pemikiran kritis penulis terhadap kualitas madrasah secara umum di Madrasah Aliyah merupakan pilihan strategis untuk mendukung kualitas pengelolaan madrasah, baik negeri maupun swasta.

Ke-delapan strategi nilai pilihan yang dimaksud oleh peneliti yaitu: (1) Kurikulumnya Inovatif, artinya sebuah madrasah yang berkualitas dapat dipastikan sistem pengembangnan kurikulumnya cenderung inovatif, dalam arti tidak statis. Pengolahan kurikulum sesuai dengan kebutuhan dan perkembangan zaman serta tingkat kemampuan peserta didik, kegiatan ekstrakurikulernya juga berkembang. (2) Jam pelajaran lebih panjang, madrasah yang berkualitas akan menyusun jadwal pelajaran bagi peserta didiknya lebih lama, artinya, pengelola madrasah akan memberikan tambahan-tambahan pelajaran untuk meningkatkan kualitas peserta didiknya, dan akan lebih baik jika diasramakan atau berbentuk boarding school. (3) Siswanya pasti banyak, dan yang antri untuk mendaftar di madrasah tersebut 
cukup banyak, Lulusannya diatas $95 \%$ dan diterima di berbagai perguruan tinggi pavorit dan memilih jurusan atau program studi yang unggul diperguruan tinggi tersebut. (4) Pendidiknya profesional, artinya madrasah yang berkualitas dapat dipastikan juga bahwa pendidik dan tenaga pendidiknya juga berkualitas, untuk menciptakan peserta didik yang pandai tentu gurunya harus pandai (berkualitas) sereta spesifik dalam keilmuannya, pendidiknya fokus mengajar di madrasah tersebut, tidak mengajar dibarbagai sekolah atau madrasah. (5) Sarana dan prasarana mendukung peserta didik dalam mengembangkan diri baik untuk academic development maupun nonacademic development. (6) Pengelolaan yang diharapkan stakeholder terpenuhi secara optimal, artinya sistem perencanaan, pelaksanaan dan evaluasi tersusun secara baik, dan dilaksanakan dengan penuh tanggungjawab, dengan demikian diharapkan madrasah tersebut pola manajemen pendidikannya tertata secara profesional. (7) Standar Pembiayaan diatas ratarata, artinya wajar untuk mencapai suatu kualitas yang baik, sebuah madrasah memerlukan biaya pengelolaan yang sedikit lebih besar dibandingkan madrasah yang biasa-biasa saja. (8) Sistem penilaian lebih obyektif, akuntabel, terbuka dan memiliki standar plus melebihi apa yang telah ditetapkan pada Standar Nasional pendidikan.

\section{PENUTUP}

Berdasarkan hasil penelitian yang telah dilakukan mengenai kualitas madrasah Aliyah dapat disimpulkan sebagai berikut;

Kualitas madrasah di Bone Bolango masih masuk dalam kategori baik, namun dalam beberapa hal terutama dari sarana dan prasarana serta pendidik dan tenaga kependidikan masih terdapat kelemahan, inilah yang perlu menjadi perhatian pemerintah, terutama Kementerian Agama, Cq. Direktur Madrasah.

Bantuan Kementerian Agama dalam upaya percepatan akreditasi sudah baik dan benar, namun perlu juga dipikirkan bantuan upaya untuk mempertahankan nilai akreditasi untuk dikembangkan hingga mencapai standar maksimal. Perlu peningkatan model pengelolaan asrama atau diistilahkan boarding yang ideal dan mencirikan sebuah madrasah.

\section{UCAPAN TERIMA KASIH}

Ucapan terima kasih kepada Balai Penelitian dan pengembangan Agama Makassar yang telah menugaskan Peneliti untuk melakukan penelitian di Gorontalo, penulis juga mengucapkan terima kasih kepada Kepala Sekolah dan Pendidik di MAN Insan Cendikia, MAS Muhammadiyah dan MAS Sabrun Jamil.

\section{DAFTAR PUSTAKA}

Amri, Sofan. 2013. Peningkatan Mutu Pendidikan Sekolah Dasar dan Menengah dalam Teori, Konsep dan Analisis. Jakarta: Prestasi Pustakarya.

Arcaro, Jerome S. 2007. Pendidikan Berbasis Mutu: Prinsip-prinsip perumusan dan Tata langkah penerapan. Yogjakarta: Pustaka Pelajar.

Asmani, Jamal Ma’mur. 2013. Kita Melahirkan Madrasah Unggulan. Yogjakarta: Diva Press.

Azra, Azyumardi. 2012. Pendidiikan Islam: Tradisi dan Modernisasi di Tengah Tantangan Milenium III. Jakarta: Prenada media Group.

Danim, Sudarwan. 2008. Visi Baru Manajemen Sekolah dari unit birokrasi ke Lembaga Akademik. Jakarta: Bumi Aksara.

Fatchurochman, Nanang, 2012. Madrasah Sekolah Islam terpadu, Plus dan Unggulan, cet. Ke-2 Depok: Lentera Hati Pustaka.

Gozali, Ima dan Umiarso, 2011. Manajemen Mutu Sekolah di Era Otonomi Pendidikan. Yogjakarta: IRCiSoD.

Hasballah. 1999, Dasar-Dasar Ilmu Pendidikan. Jakarta: Raja Grafindo Persada

Nata, Abudin. 2003. Kapita Selekta Pendidikan Islam Bandung: Penerbit Angkasa

Nata, Abudin. 2012. Sejarah Sosial Intelektual Islam dan Institusi Pendidikannya. Jakarta: Rajawali Press.

Peraturan Pemerintah Nomor 32 tahun 2013 tentang perubahan atas Peraturan Pemerintah No. 19 tahun 2005 tentang Standar Nasional Pendidikan

Peraturan Presiden Nomor 5 athun 2010 tentang Rencana Pembangunan Jangka Menengah Nasional 2010-2014

Soekartawi, MS, dkk, 1995.Meningkatkan Rancangan Instruksional, Jakarta: Raja Grafindo Persada, 
Subhan, Arief. 2012. Lembaga Pendidikan Islam Indonesia Abad ke-20; pergumulan Antara Modernisasi dan Identitas. Jakarta: Prenada Media Group.

Sukmadinata, dkk. 2008. Pengendalian Mutu Pendidikan sekolah Memengah. (Konsep, Prinsip dan Instrumen). Bandung: Refika Aditama.
Suryosubroto, B. 2004. Manajemen Pendidikan Sekolah. Jakarta: Rineka Cipta.

Sutikno, M. Sobry. 2012. Manajemen Pendidikan, Langkah Praktis Mewujudkan Lembaga Pendidikan yang Unggul (Tinjauan Umum dan Islam). Lombok: Holistica.

Zazin, Nur. 2011. Gerakan Menata Mutu Pendidikan. Yogjakarta: Ar-Ruzz Media. 